\title{
Dissolved ATP turnover in the Bransfield Strait, Antarctica during a spring bloom
}

\author{
Michele P. Nawrocki ${ }^{1}$, David M. Karl ${ }^{1,2, *}$ \\ 'Department of Oceanography, University of Hawaii, Honolulu, Hawaii 96822, USA \\ ${ }^{2}$ Division of Oceanic Biology, Hawaii Institute of Geophysics, University of Hawaii, Honolulu, Hawaii 96822, USA
}

\begin{abstract}
Ambient concentrations and turnover rates of dissolved adenosine triphosphate (D-ATP) were measured at 5 stations in the Bransfield Strait, Antarctica during the 1986-87 Research on Antarctic Coastal Ecosystem Rates (RACER) field program. The study area was pre-selected to include several different coastal and oceanic habitats expected to vary considerably in timing and magnitude of the annual spring phytoplankton bloom. D-ATP concentrations varied both spatially and temporally during the 4 mo of observation. During the initial stages of bloom development, there was a significant positive correlation between the concentration of particulate (P) ATP (i.e. biomass) and D-ATP; however, this relationship deteriorated later in the season. At the height of the spring bloom (January), we observed a D-ATP concentration gradient in excess of an order of magnitude for our coastal to open ocean transect. Dissolved ATP fluxes (uptake rate times ambient concentration; $\mathrm{ng} \mathrm{l}^{-1} \mathrm{~d}^{-1}$ ) were highly correlated with D-ATP concentrations, indicating that bloom conditions stimulated both production and removal processes. We assessed the potential role of 3 independent processes as a source of D-ATP in Antarctic coastal waters: excretion/exudation, production during micro- or macrozooplankton grazing and cell death/autolysis. Results are most consistent with a model that includes phytoplankton release during active growth and metabolism as a major source of D-ATP in our study area.
\end{abstract}

\section{INTRODUCTION}

Dissolved organic matter (DOM) in the world's oceans is one of the largest reservoirs of organic carbon on earth. Allochthonous sources of DOM, including riverine and aeolian transport, are generally considered to be of minor importance compared to in situ DOM production processes. In the ocean, DOM is believed to be formed from the combined effects of algal excretion and exudation, release during microand macrozooplankton grazing activities and as a result of death and autolysis at all trophic levels. The turnover of DOM is controlled primarily by the metabolic activities of microheterotrophs, especially bacteria (Wiebe \& Smith 1977, Lancelot 1979, Larsson \& Hagström 1979, Iturriaga 1981, Wolter 1982). Consequently, both the steady-state concentration of DOM and turnover rates might be expected to correlate with the distribution and metabolic activities of marine microorganisms.

Recently, Williams \& Druffle (1987) have presented evidence, based on ${ }^{14} \mathrm{C}$ measurements, which indicates

\footnotetext{
- Addressee for correspondence
}

that the mean age of the DOM pool in the North Pacific Ocean ranges from 1000 yr near the surface to $>6000$ yr at abyssal depths. If DOM is rapidly recycled by the combined activities of photosynthetic and heterotrophic microorganisms in the surface ocean, then it is difficult to reconcile that ecological model with the directly measured DOM age determinations for surface water DOM. One acknowledged complication of studies involving total DOM is the uncertainty in the molecular composition of this heterogeneous pool and the variability which undoubtedly exists in the turnover rates of its individual constituents. In this regard, surface water DOM with a mean ${ }^{14} \mathrm{C}$ age of 1000 yr could theoretically be comprised of 2 (or more) sub-pools of equal mass; one active fraction with a $1 \mathrm{~d}$ turnover time and a second inactive fraction with a 2000 yr turnover time. Consequently, in order to quantify the rates and mechanisms of DOM cycling in the marine environment it is imperative to focus on the in situ production and biological uptake of specific classes of organic compounds, rather than the total heterogeneous DOM pool.

One specific constituent of the total DOM pool which has been studied in the marine environment is 
adenosine-5'-triphosphate (ATP). While ATP is biologically labile, it is chemically stable, with a half-life in artificial seawater at $21^{\circ} \mathrm{C}$ of ca 8 yr (Hulett 1970). Azam \& Hodson (1977) first reported the occurrence of dissolved ATP (D-ATP) in coastal seawaters off Southern California, USA (range of concentrations: 100 to $600 \mathrm{ng} \mathrm{l}^{-1} ; 0.2$ to $1.2 \mathrm{nM}$ ). They discussed the potential importance of D-ATP as a tracer of DOM and provided the first concentration versus depth profile of D-ATP. Two striking features of that profile were: (1) the small concentration change with depth, despite order of magnitude changes in biomass and (2) the observation that the deep water $(>250 \mathrm{~m})$ D-ATP concentrations were approximately an order of magnitude greater than the particulate ATP (P-ATP) concentrations. It was also determined that ATP was actively 'removed' from seawater at rates greatly in excess of those predicted from the above-mentioned laboratory studies on chemical stability. Possible mechanisms of D-ATP removal were attributed to spontaneous hydrolysis, enzymatic degradation and microbiological uptake. Direct measurements of DATP assimilation and incorporation by marine bacteria provided support for the role of heterotrophic microorganisms (Azam \& Hodson 1977).

Subsequent research efforts reported D-ATP concentrations and/or uptake rates from seawater samples collected beneath the Ross Ice Shelf, Antarctica (Azam et al. 1979), in McMurdo Sound, Antarctica (Hodson et al. 1981a) and off the southeastern coast of the USA (Hodson et al. 1981b). McGrath \& Sullivan (1981) presented a first-order model of adenylate cycling within Los Angeles Harbor and Southern California coastal waters. They identified major fluxes occurring in 3 distinct compartments (dissolved total adenylates, particulate adenylates of the bacterioplankton-enriched fraction and particulate adenylates of the phyto- and microzooplankton-enriched fraction), and determined the compartment sizes, rates of uptake and rates of bactivory. There seems little doubt from the abovementioned studies that D-ATP is a ubiquitous constituent of the oceanic DOM pool and that heterotrophic bacteria are a sink for D-ATP.

The first attempts to specifically study D-ATP production were in the freshwater studies of Riemann (1979) and Maki et al. (1983). Working in 2 eutrophic Danish lakes, Riemann (1979) found an increase in the concentration of D-ATP after the culmination of spring diatom blooms, when chlorophyll a values had already decreased to pre-bloom values. He attributed the increase in D-ATP concentration to algal cell lysis. In his study, zooplankton were reported as not abundant'. Makı et al. (1983) investigated the effects of feeding by the oppossum shrimp Mysis relicta on the cycling of ATP in Lake Michigan, USA. Feeding by this herbivore was shown to decrease P-ATP, but apparently did not cause the release of D-ATP. It was suggested that $M$. relicta may be a relatively efficient particle feeder and did not produce large amounts of DOM during the process of food ingestion. Berman et al. (1987) measured D-ATP and P-ATP levels in laboratory studies of microbial food web-induced nutrient flux. Batch cultures which contained nanoprotist grazers along with bacteria and algae showed elevated concentrations of D-ATP and D-ATP/P-ATP ratios greater than 1. Flasks with only exponentially-growing bacteria and/or algae had persistently low levels of DATP (Berman et al. 1987). The differing results of these studies leave grazing by nanoplanktonic protists and algal cell lysis as possible sources of D-ATP in the marine environment

During a recent interdisciplinary oceanographic field study in the Bransfield Strait, Antarctica (Research on Antarctic Coastal Ecosystem Rates [RACER]), we had an opportunity to investigate P-ATP and D-ATP pool dynamics in conjunction with comprehensive measurements of upper ocean physics, photosynthetic and bacterial processes, vertical flux of organic matter and distribution and physiological rates of planktonic protists, zooplankton and krill (Huntley et al. 1987). Our results indicate that D-ATP is present in both coastal and open ocean Antarctic habitats, is rapidly taken up by microheterotrophic assemblages and is apparently produced primarily through the process of algal cell exudation rather than by algal cell lysis or grazing activities of micro- or macrozooplankton.

\section{MATERIALS AND METHODS}

Station locations, method of water collection and sampling schedule. At 5 selected sites in the RACER study area (Stns 13, 20,39, 43 and 48; Fig. 1), we performed in situ productivity and sediment trap experiments and had an opportunity to conduct more detailed experiments on the physiological ecology of bacteria, phytoplankton and zooplankton. These stations comprised the full range of microbial biomass and productivity observed during the RACER program. From an analysis of the hydrographic data collected during RACER, Niiler et al. (unpubl.) conclude that, in spite of the complexity of the region, the water mass structure is conserved throughout the period of aur investigation. Consequently, the temporal and spatial variations that we report herein are likely to have a sound biological basis.

Water samples for D-ATP determinations were obtained from depths of 0 to $100 \mathrm{~m}$ using $10 \mathrm{l}$ Niskin bottles (General Oceanics, Miami, Florida, USA). Large particles and macrozooplankton were removed by 


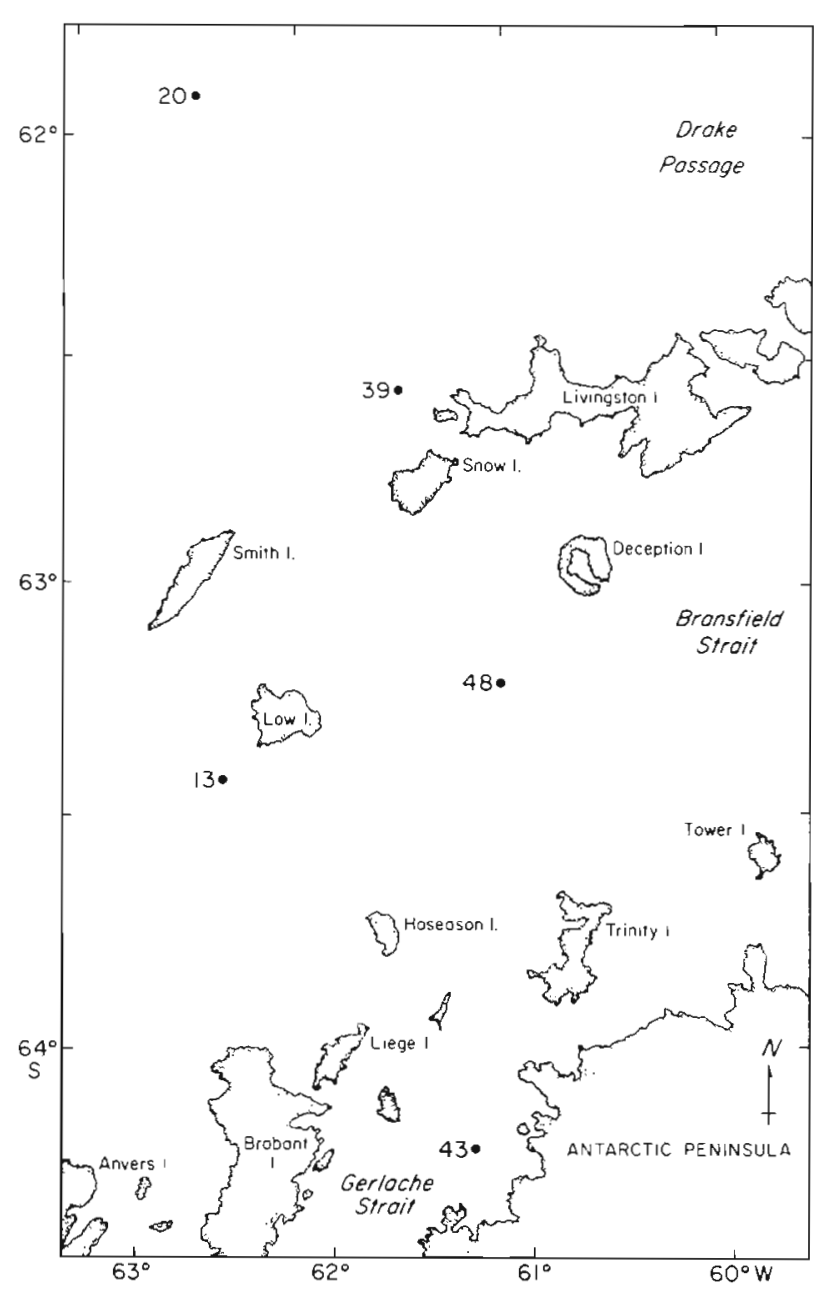

Fig. 1. The RACER study area showing locations of stations occupied during the field experiment

passing the seawater through a $202 \mu \mathrm{m}$ Nitex ${ }^{(B)}$ mesh during the initial subsampling procedures. A portion of the $<202 \mu \mathrm{m}$ water sample was further fractionated by passing it through a $20 \mu \mathrm{m}$ Nitex ${ }^{3}$ screen. The $<202 \mu \mathrm{m}$ and $<20 \mu \mathrm{m}$ subsamples were held in polycarbonate bottles at ambient temperature $\left(-1.5\right.$ to $\left.2.0^{\circ} \mathrm{C}\right)$ and protected from direct sunlight for a maximum of $2 \mathrm{~h}$ during sample processing.

Particulate ATP (P-ATP) extraction and analysis. Particulate materials from the $<202 \mu \mathrm{m}$ and $<20 \mu \mathrm{m}$ samples were concentrated onto glass fiber filters (Whatman GF/F), immediately immersed in boiling phosphate buffer $(60 \mathrm{mM}, \mathrm{pH} 7.4)$ and extracted at $100^{\circ} \mathrm{C}$ for $5 \mathrm{~min}$. The samples were stored frozen $\left(-20^{\circ} \mathrm{C}\right)$ for subsequent laboratory analysis using the firefly bioluminescence assay procedure (Karl \& HolmHansen 1978).

Dissolved ATP (D-ATP) extraction and analysis. DATP determinations were obtained using a procedure that was modified from Hodson et al. (1976) and Fel- lows et al. (1981). Samples for D-ATP analysis were prepared by passing the filtrate from the P-ATP preparations through a $0.22 \mu \mathrm{m}$ cellulose acetate filter (GS type; Millipore Corporation, Bedford, Mass., USA) to remove any particles which may have passed through the GF/F filter. A $300 \mathrm{ml}$ sample of the $0.22 \mu \mathrm{m}$ filtrate was acidified with $\mathrm{H}_{3} \mathrm{PO}_{4}$ to a final concentration of $1 \mathrm{M}$, and stored at $-20{ }^{\circ} \mathrm{C}$ for a period not exceeding $14 \mathrm{~d}$. At Palmer Station, Antarctica, the samples were thawed at $4{ }^{\circ} \mathrm{C}$ and $5 \mathrm{ml}$ of an activated charcoal suspension $\left(100 \mathrm{mg} \mathrm{ml}^{-1}\right.$ in $\left.0.1 \mathrm{MH}_{3} \mathrm{PO}_{4}\right)$ was added to duplicate samples $(142 \mathrm{ml})$ contained in $150 \mathrm{ml}$ polycarbonate centrifuge tubes. The samples were shaken by hand for $15 \mathrm{~min}$, centrifuged for $10 \mathrm{~min}$ at $1650 \times \mathrm{g}$ and the supernatants discarded. The charcoal slurries, with adsorbed ATP, were transferred quantitatively to $16 \times 150 \mathrm{~mm}$ test tubes, and centrifuged for $10 \mathrm{~min}$. The supernatants were discarded and the charcoal pellets were stored frozen $\left(-20^{\circ} \mathrm{C}\right)$ for subsequent analysis. At the University of Hawaii, the samples were thawed and desalted by resuspending the pellet twice with $12 \mathrm{ml} 0.01 \mathrm{M} \mathrm{HCl}$. The ATP was then eluted from the charcoal during a $1 \mathrm{~h}$ batch extraction with $10 \mathrm{ml}$ of a solution containing $95 \%$ ethanol, distilled water and $14.2 \mathrm{MNH}_{4} \mathrm{OH}$ in a ratio of $150: 80: 50$, by volume. The samples were centrifuged $(1650 \times g)$, filtered (Whatman GF/F) and dried in vacuo. The concentrated ATP samples were dissolved in $1 \mathrm{ml}$ Tris buffer $(20 \mathrm{mM}$. $\mathrm{pH} 7.7$ ) and assayed using the firefly bioluminescence procedure, as described above. ATP standards, prepared in Antarctica using $0.22 \mu \mathrm{m}$ filtered seawater, were used to evaluate, and correct for, all potential losses of ATP including incomplete binding of ATP to charcoal, incomplete desorption, hydrolysis during storage and processing and any of a variety of potential interferences with the luciferase-luciferin bioluminescence reaction.

D-ATP uptake. D-ATP uptake was measured by the addition of $15 \mu \mathrm{Ci}$ of $\left[2,8,{ }^{3} \mathrm{H}\right]$-ATP (New England Nuclear \# 24009, specific activity $32 \mathrm{Ci} \mathrm{mmol}^{-1}$ ) to $15 \mathrm{ml}$ of the $<202 \mu \mathrm{m}$ seawater samples. A subsample $(5 \mathrm{ml})$ was removed immediately and stored at $-20^{\circ} \mathrm{C}$. The remaining $10 \mathrm{ml}$ portion was incubated in the dark at in situ water temperature for $12 \mathrm{~h}$, at which time the entire sample was filtered through a GF/F filter. The filter and fitrate were stored at $-20^{\circ} \mathrm{C}$ for subsequent shore-based analysis of the radioactivity using a Packard TriCarb 4640 liquid scintillation counter. D-ATP turnover time was calculated as described by Azam \& Holm-Hansen (1973).

Adenylate energy charge. Adenylate energy charge $\left(E_{A}\right)$ was calculated from measurements of ATP, ADP and AMP using the enzymatic methods of Karl \& HolmHansen (1978), ECA was determined for total particulate $(<202 \mu \mathrm{m})$ and dissolved sample preparations. 


\section{RESULTS}

\section{D-ATP depth profiles}

Depth profiles from the 5 RACER stations sampled on 4 cruises indicate that D-ATP was present in Antarctic coastal and open ocean ecosystems throughout the spring/summer season (Fig. 2) and, furthermore, demonstrate the existence of substantial variability in time and space. In general, the highest D-ATP concentrations were in the surface waters $(<15 \mathrm{~m})$ and coincided with the peaks in total microbial biomass, as determined by P-ATP and chlorophyll a (Holm-Hansen et al. 1987, Tien et al. 1987, Karl et al. unpubl.). Maximum surface concentrations of D-ATP (>1000 $\mathrm{ng} \mathrm{I}^{-1}$ ) were observed in the coastal shelf habitats (Stns 13 and 43) with the lowest surface water concentrations $(<150$ $\mathrm{ng} \mathrm{l}^{-1}$ ) measured at the Drake Passage station (Stn 20). Peak concentrations at a given station occurred in December (Stns 39 and 48) or January (Stns 13, 20 and $43)$, with decreasing concentrations throughout the late summer season. Stn 43, where the spring phytoplankton bloom was most intense, supported the largest seasonal fluctuations in D-ATP.
Overall, we observed a positive correlation between $\mathrm{P}$ ATP and D-ATP in time and space (model 2 linear regression analysis, Laws \& Archie 1981; $\mathrm{r}^{2}=0.76$ $n=142$ ). However, when the complete data set was analyzed on a station-by-station, month-by-month basis, a more predictable pattern emerged (Table 1). In December 1986, during the spring bloom period, high correlation coefficients $(0.91$ to 0.94$)$ between $P$-ATP and D-ATP were observed for every station sampled (Table 1). The close covariance between P-ATP and D-ATP persisted through February 1987 at Stns 43 and 48, but began to deteriorate at the other sites. By the end of the summer season (March 1987), the slope of the regression between P-ATP and D-ATP was negative rather than positive (Table 1). From these data, we conclude that DATP is produced as a result of the net growth of microorganisms during the Antarctic spring bloom rather than as a result of net cell death and autolysis which occurs later in the season (February-March)

\section{Depth-integrated D-ATP}

D-ATP concentrations were integrated over 0 to $50 \mathrm{~m}$ and 0 to $100 \mathrm{~m}$ depth intervals for all stations (Table 2).

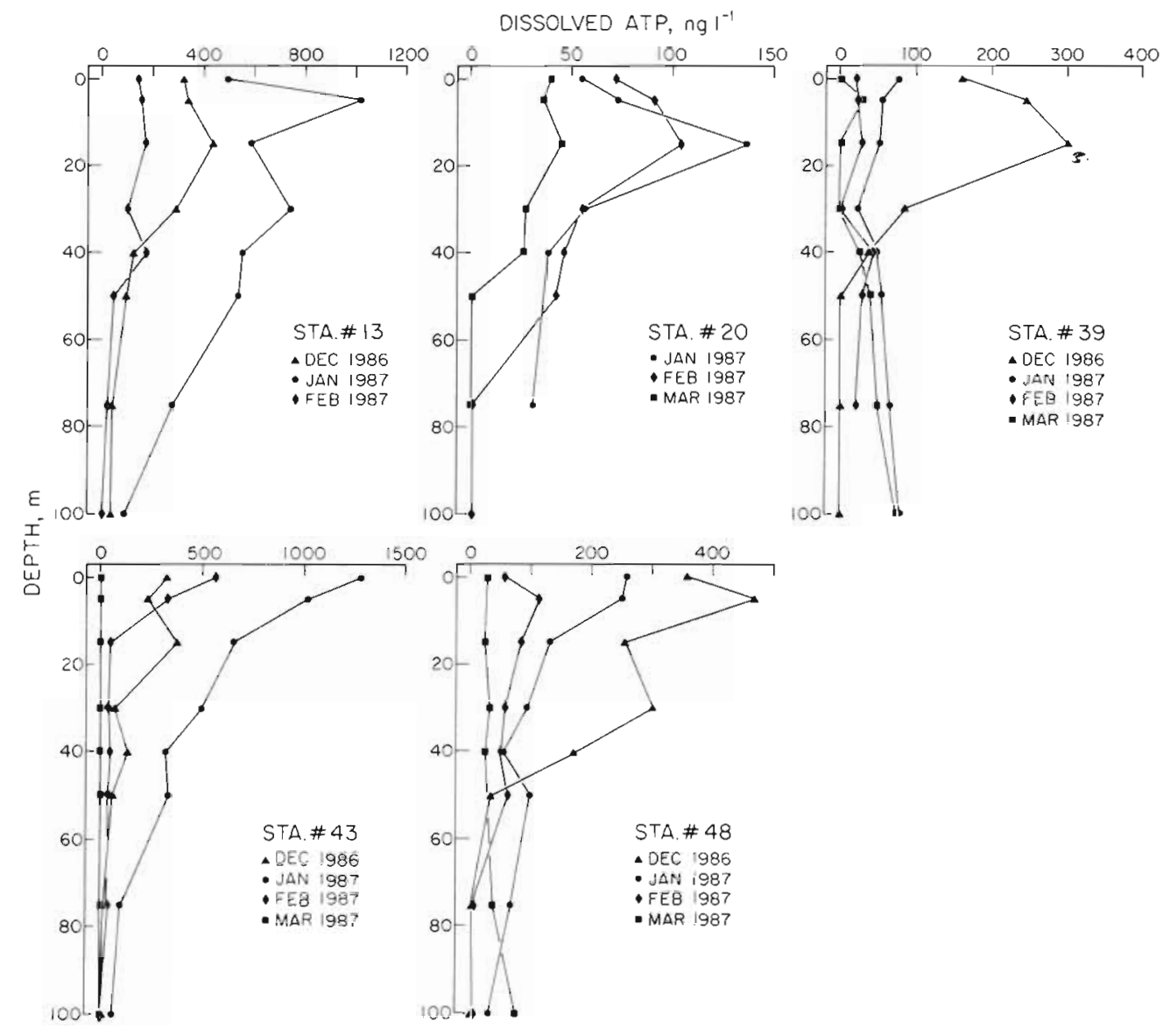

Fig. 2. Temporal changes in the concentrations of D-ATP versus depth measured dunng the $1986-87$ austral summer 
Table 1. Linear regression analyses (model 2 analysis; Laws \& Archie 1981) of P-ATP and D-ATP concentrations for depth profiles in the RACER study area

\begin{tabular}{|c|c|c|c|c|c|c|c|c|}
\hline \multirow{2}{*}{ Station } & \multicolumn{2}{|c|}{ Dec } & \multicolumn{2}{|c|}{ Jan } & \multicolumn{2}{|c|}{ Feb } & \multicolumn{2}{|c|}{ Mar } \\
\hline & Slope & $r^{2}$ & Slope & $r^{2}$ & Slope & $r^{2}$ & Slope & $r^{2}$ \\
\hline 13 & 1.29 & 0.94 & 0.56 & 0.63 & 0.54 & 0.70 & \multicolumn{2}{|c|}{$-{ }^{d}$} \\
\hline 20 & \multicolumn{2}{|c|}{$-^{a}$} & 1.33 & 0.51 & 1.25 & 0.74 & -1.57 & -0.66 \\
\hline 39 & 2.38 & 0.91 & -1.39 & -0.64 & -0.19 & -0.08 & -0.14 & -0.34 \\
\hline 43 & 2.34 & 0.94 & 0.90 & 0.96 & 1.76 & 0.97 & -5.78 & -0.40 \\
\hline 48 & 1.37 & 0.90 & 3.37 & 0.96 & 1.94 & 0.84 & -0.23 & -0.02 \\
\hline
\end{tabular}

The amount of D-ATP present in the upper $50 \mathrm{~m}$ of the water column was $\geq 60 \%$ of the total D-ATP 10 to $100 \mathrm{~m}$ ) early in the season but, as reflected in the more constant depth profiles seen in February and March, this proportion tended to decrease as the season progressed. The seasonal D-ATP concentrations were least variable at the well-mixed station in the Drake Passage (Stn 20). Depth-integrated ( 0 to $50 \mathrm{~m}$ and 0 to $100 \mathrm{~m}$ ) DATP concentrations were also compared with simultaneously collected depth-integrated P-ATP $(<202 \mu \mathrm{m})$ data, representing total microbial biomass (Table 2). With the exception of the Stn 43 March 1987 results, DATP concentrations varied from 14.4 to $72.6 \%$ of the total water column ATP (dissolved plus particulate) with no consistent temporal or spatial trends.

\section{D-ATP uptake}

Preliminary experiments conducted on the December 1986 RACER cruise indicated that D-ATP was rapidly assimilated by microorganisms present in the water column and that the uptake rates were linear for at least $24 \mathrm{~h}$ at in situ water temperatures. During the January 1987 RACER cruise, D-ATP uptake rate and turnover time were measured at all 5 stations and for all water depths sampled (Table 3 ; Fig. 3). D-ATP turnover times ranged from 79 to $>600 \mathrm{~h}$, and were generally more rapid in the upper 0 to $30 \mathrm{~m}$ of the water column. With the exception of Stn 20, the most rapid turnover times were associated with the highest D-ATP water column concentrations indicating what we interpret to be a rapid recycling (production coupled to uptake) of DATP. These data support the hypothesis that ATP is rapidly produced in the euphotic zone of the water column and is coupled to primary production processes.

\section{Dissolved and particulate adenylate energy charge ratios}

$\mathrm{EC}_{\mathrm{A}}$ ratios were calculated for dissolved and total particulate $(<202 \mu \mathrm{m})$ samples. Dissolved ratios were compared to the particulate ratios using the 0 to $50 \mathrm{~m}$ mean ( \pm 1 standard deviation) values for the 5 stations on all 4 cruises (Table 4; Fig. 4). Several consistent patterns emerged, including: (1) particulate $\mathrm{EC}_{\mathrm{A}}$ ratios exhibited only a small range throughout the entire season and study area and, with one exception (Stn 39, March 1987), varied from 0.58 to 0.74 ; (2) the mean total microbial community $\mathrm{EC}_{\mathrm{A}}$ values were consistently below the theoretical minimum of 0.8 that is required for net growth to occur (Chapman \& Atkinson 1977); (3) dissolved $E_{A}$ exhibited a much wider range in values, from 0.25 to 0.71 ; and (4) early (December 1986) season particulate and dissolved $\mathrm{EC}_{\mathrm{A}}$ were indistinguishable at all stations, but diverged widely thereafter with dissolved $\mathrm{EC}_{\mathrm{A}}$ ratios being consistently less than the corresponding particulate $\mathrm{EC}_{\mathrm{A}}$ ratios.

\section{DISCUSSION}

Although D-ATP makes up only a small fraction of the DOM pool (i.e. $0.001 \%$ of DOC), the sensitivity with which it can be measured (detection limit ca $1 \mathrm{ng}$ $1^{-1}$ ), its apparent rapid turnover in seawater and its strict biological origin provide a unique basis for establishing the mechanism of transfer from POM to DOM (Azam \& Hodson 1977, McGrath \& Sullivan 1981). Dissolved nucleotides are both produced and taken up by microorganisms within seawater, i.e. they undergo turnover. The steady-state concentrations measured in the present study area are a reflection of these $2 \mathrm{com}$ peting processes. During the initial stages of the spring bloom, algal growth processes would be expected to dominate over microheterotrophic production or protozoan/metazoan grazing activities. If excretion/leakage of ATP from viable phytoplankton cells is the principle mechanism for D-A.TP production, then one might expect to observe an uncoupling of D-ATP production from D-ATP consumption, resulting in a transient accumulation of D-ATP in the water column during the initiation and development of the bloom (NovemberDecember). If, on the other hand, D-ATP is derived 
Table 2. Comparison of 0 to $50 \mathrm{~m}$ and 0 to $100 \mathrm{~m}$ depth-integrated D-ATP and P-ATP water column inventories for 5 selected RACER stations from December 1986 to March 1987

\begin{tabular}{|c|c|c|c|c|c|c|c|}
\hline Station & Month & $\begin{array}{c}0-50 \mathrm{~m} \\
\text { D-ATP } \\
\left(\mathrm{mg} \mathrm{m}^{-2}\right)\end{array}$ & $\begin{array}{c}0-100 \mathrm{~m} \\
\text { D-ATP } \\
\left(\mathrm{mg} \mathrm{m}^{-2}\right)\end{array}$ & $\begin{array}{c}0-50 \mathrm{~m} \\
\text { P-ATP } \\
\left(\mathrm{mg} \mathrm{m}^{-2}\right)\end{array}$ & $\begin{array}{l}0-100 \mathrm{~m} \\
\text { P-ATP } \\
\left(\mathrm{mg} \mathrm{m}^{-2}\right)\end{array}$ & $\begin{array}{c}0-50 \mathrm{~m} \\
\frac{D-A T P}{[D-A \cdot \bar{T} P+P-A T P]} \\
(\%)\end{array}$ & $\begin{array}{c}0-100 \mathrm{~m} \\
\frac{\text { D-ATP }}{[\mathrm{D}-\mathrm{ATP}+\mathrm{P}-\mathrm{ATP}]} \\
(\%)\end{array}$ \\
\hline 13 & $\begin{array}{l}\text { Dec } 1986 \\
\text { Jan } 1987 \\
\text { Feb } 1987\end{array}$ & $\begin{array}{r}14.1 \\
33.7 \\
6.9\end{array}$ & $\begin{array}{r}16.6 \\
48.4 \\
8.1\end{array}$ & $\begin{array}{r}25.9 \\
25.0 \\
2.6\end{array}$ & $\begin{array}{r}35.7 \\
34.6 \\
3.5\end{array}$ & $\begin{array}{l}35.3 \\
57.4 \\
72.6\end{array}$ & $\begin{array}{l}31.7 \\
58.5 \\
69.8\end{array}$ \\
\hline 20 & $\begin{array}{l}\text { Jan } 1987 \\
\text { Feb } 1987 \\
\text { Mar } 1987\end{array}$ & $\begin{array}{l}3.7 \\
3.5 \\
1.5\end{array}$ & $\begin{array}{l}5.9 \\
4.0 \\
1.5\end{array}$ & $\begin{array}{r}12.5 \\
6.5 \\
5.4\end{array}$ & $\begin{array}{r}17.0 \\
8.6 \\
8.9\end{array}$ & $\begin{array}{l}22.8 \\
35.0 \\
21.7\end{array}$ & $\begin{array}{l}25.8 \\
31.8 \\
14.4\end{array}$ \\
\hline 39 & $\begin{array}{l}\text { Dec } 1986 \\
\text { Jan } 1987 \\
\text { Feb } 1987 \\
\text { Mar } 1987\end{array}$ & $\begin{array}{l}7.5 \\
2.3 \\
1.0 \\
0.5\end{array}$ & $\begin{array}{l}7.5 \\
5.7 \\
2.2 \\
3.2\end{array}$ & $\begin{array}{c}25.7 \\
10.3 \\
3.5 \\
2.2\end{array}$ & $\begin{array}{r}31.7 \\
18.0 \\
5.3 \\
4.5\end{array}$ & $\begin{array}{l}22.6 \\
18.3 \\
22.2 \\
18.5\end{array}$ & $\begin{array}{l}19.1 \\
24.1 \\
29.3 \\
41.6\end{array}$ \\
\hline 43 & $\begin{array}{l}\text { Dec } 1986 \\
\text { Jan } 1987 \\
\text { Feb } 1987 \\
\text { Mar } 1987\end{array}$ & $\begin{array}{r}9.7 \\
30.1 \\
5.7 \\
<0.1\end{array}$ & $\begin{array}{r}10.4 \\
37.5 \\
7.0 \\
0.2\end{array}$ & $\begin{array}{r}49.5 \\
49.8 \\
22.4 \\
5.8\end{array}$ & $\begin{array}{r}75.4 \\
73.0 \\
34.5 \\
9.9\end{array}$ & $\begin{array}{l}16.4 \\
37.7 \\
20.3 \\
<2.0\end{array}$ & $\begin{array}{r}12.1 \\
33.9 \\
16.9 \\
2.0\end{array}$ \\
\hline 48 & $\begin{array}{l}\text { Dec } 1986 \\
\text { Jan } 1987 \\
\text { Feb } 1987 \\
\text { Mar } 1987\end{array}$ & $\begin{array}{r}13.2 \\
6.3 \\
3.6 \\
1.4\end{array}$ & $\begin{array}{r}13.6 \\
9.6 \\
4.4 \\
3.5\end{array}$ & $\begin{array}{r}27.4 \\
26.4 \\
9.9 \\
6.4\end{array}$ & $\begin{array}{r}33.8 \\
35.6 \\
14.4 \\
9.5\end{array}$ & $\begin{array}{l}32.5 \\
19.3 \\
26.7 \\
17.9\end{array}$ & $\begin{array}{l}28.7 \\
21.2 \\
23.4 \\
26.9\end{array}$ \\
\hline
\end{tabular}

primarily from the feeding activities of macro- or microzooplankton or as a result of cell death/autolysis one would expect to observe a transient accumulation of D-ATP during the decline of the spring bloom cycle (February-March).

The detection of D-ATP at all stations during the 4 mo RACER program confirmed that D-ATP is a ubiquitous component of the DOM pool of Antarctic ecosystems. D-ATP concentrations varied over 3 orders of magnitude from $<1.0$ to $>1000 \mathrm{ng} \mathrm{D-ATP} \mathrm{l}^{-1}$. The spatial and temporal variability observed reflects the complex physical character of the area and the attendant biological processes. One distinct feature was an inshore-offshore gradient in D-ATP concentration. Large accumulations of D-ATP occurred in the protected embayment of Gerlache Strait and in the shallow, vertically well-mixed water of the frontal zone, but D-ATP concentrations were substantially lower at offshore stations and at the deep water station of the Bransfield Strait. D-ATP is apparently either advected into the Peninsula area from a region with even higher D-ATP concentration or is produced as the result of local biological activity. Although we favor the latter mechanism, our present study was insufficient to resolve between D-ATP production and advection because we did not assess D-ATP production directly. However, without a continuous source of D-ATP for surface seawaters in the RACER study area, the measured uptake rates would be sufficient to reduce the ambient D-ATP concentrations to below our detection limits in a period of ca 1 to $2 \mathrm{wk}$ as the water advected through the study area.

We evaluated 3 possible mechanisms of D-ATP production, including: (a) cell death and autolysis, (b) extracellular release and (c) release of cell contents during grazing activity. We predicted that if D-ATP was produced as a result of cell death, a D-ATP peak would occur with the decline of biomass, as reported by Riemann (1979); i.e. in late summer (February-March). Instead, a comparison of P-ATP and D-ATP concentrations showed a high degree of correlation between these 2 parameters (Tables 1 and 2). P.ATP was high during the first sampling in December and remained high in January, Later in the season, D-ATP declined concomitant with P-ATP. Overall, there was a significant and positive correlation between P- and D-ATP measurements, especially in the early portion of the season (Table 1). Consequently, we conclude that the concentration of D-ATP is positively correlated with microbial biomass.

D-ATP was already present throughout the RACER study area in December, at the measured height of phytoplankton productivity (Holm-Hansen et al. 1987). At this point, the mean intracellular $\mathrm{EC}_{\mathrm{A}}$ of the total microbial community $(<202 \mu \mathrm{m})$ was slightly less than the 0.8 value that is indicative of a healthy, nonstressed population (Karl 1980). There are 2 possible explanations for this result: (1) the population as a 
Table 3. Water column depth profiles of D-ATP uptake rate and estimated turnover time for 5 stations in the RACER study area in January 1987

\begin{tabular}{|c|c|c|c|c|}
\hline Station & $\begin{array}{l}\text { Water } \\
\text { depth } \\
\text { (m) }\end{array}$ & $\begin{array}{c}\text { D-ATP } \\
\text { concentration } \\
\left(\text { ng } l^{-1}\right)\end{array}$ & $\begin{array}{l}\text { D-ATP } \\
\text { turnover } \\
\text { time (d) }\end{array}$ & $\begin{array}{c}\text { D-ATP } \\
\text { uptake rate } \\
\left(\text { ng } l^{-1} d^{-1}\right)\end{array}$ \\
\hline \multirow[t]{8}{*}{13} & 0 & 496 & 6.3 & 79 \\
\hline & 5 & 1019 & 8.9 & 114 \\
\hline & 15 & 584 & 6.3 & 92 \\
\hline & 30 & 742 & 11.9 & 62 \\
\hline & 40 & 552 & 17.3 & 32 \\
\hline & 50 & 537 & 11.9 & 45 \\
\hline & 75 & 276 & 14.7 & 19 \\
\hline & 100 & 87 & 10.9 & 8 \\
\hline \multirow[t]{6}{*}{20} & 0 & 55 & 3.9 & 14 \\
\hline & 5 & 73 & 4.9 & 15 \\
\hline & 15 & 137 & 7.5 & 18 \\
\hline & 30 & 56 & 18.5 & 3 \\
\hline & 40 & 38 & 7.9 & 5 \\
\hline & 75 & 30 & $>25$ & $<1$ \\
\hline \multirow[t]{8}{*}{39} & 0 & 77 & $>25$ & $<1$ \\
\hline & 5 & 55 & 19.2 & 3 \\
\hline & 15 & 52 & 22.7 & 2 \\
\hline & 30 & 23 & $>25$ & $<1$ \\
\hline & 40 & 47 & $>25$ & $<1$ \\
\hline & 50 & 56 & $>25$ & $<1$ \\
\hline & 75 & 67 & 17.8 & 4 \\
\hline & 100 & 79 & $>25$ & $<1$ \\
\hline \multirow[t]{8}{*}{43} & 0 & 1278 & 3.3 & 388 \\
\hline & 5 & 1019 & 6.2 & 165 \\
\hline & 15 & 657 & 6.0 & 110 \\
\hline & 30 & 496 & 6.0 & 83 \\
\hline & 40 & 322 & 11.6 & 28 \\
\hline & 50 & 334 & $>25$ & $<1$ \\
\hline & 75 & 97 & 6.5 & 15 \\
\hline & 100 & 59 & 19.3 & 3 \\
\hline \multirow[t]{8}{*}{48} & 0 & 258 & 4.0 & 65 \\
\hline & 5 & 250 & 7.2 & 35 \\
\hline & 15 & 131 & 7.4 & 18 \\
\hline & 30 & 93 & 21.9 & 4 \\
\hline & 40 & 52 & $>25$ & $<1$ \\
\hline & 50 & 98 & $>25$ & $<1$ \\
\hline & 75 & 66 & 19.3 & 3 \\
\hline & 100 & 28 & $>25$ & $<1$ \\
\hline
\end{tabular}

whole was physiologically stressed and the energy charge of all cells was on the decline, or (2) the population was heterogeneous, comprised of both healthy cells with a relatively high energy charge and dying or dead cells with a relatively low energy charge, the average of which resulted in a less than optimal measured value. The high rates of phytoplankton and microheterotrophic production (Bailiff et al. 1987. Holm-Hansen et al. 1987) demonstrate that this was not a senescent population. It was more likely to be an association of actively growing cells with dead, dying or dormant cells. In this regard it is worthwhile to point out that diatom resting spores, which were common in the water column throughout the period of our observations (Karl et al. unpubl.), might also contribute to the relatively low $\mathrm{EC}_{\mathrm{A}}$ measured for the particulate materials. Jewson et al. (1981) have previously shown that the $\mathrm{EC}_{\mathrm{A}}$ ratio of a diatom-dominated phytoplankton crop in Lough Neagh (N. Ireland) undergoes a systematic shift from a value of 0.8 to 0.5 as resting spore formation takes place.

In addition to particulate $\mathrm{EC}_{\mathrm{A}}$ ratios, we also measured the $E C_{A}$ of the dissolved adenine nucleotide pools. To our knowledge, these are the first dissolved $\mathrm{EC}_{\mathrm{A}}$ data to be reported. Although McGrath \& Sullivan (1981) previously presented total adenine nucleotide pool (ATP + ADP + AMP) data for coastal waters off Southern California, they did not include or discuss any $\mathrm{EC}_{\mathrm{A}}$ values. It was our belief that comparisons of the particulate and dissolved $E_{A}$ for the same water mass might help to identify, or eliminate, certain processes involved in the potential production of dissolved nucleotides. Our results indicate that the dissolved $E_{A}$ ratios at each station during the December cruise were indistinguishable from the corresponding particulate $E_{A}$ ratios for each water mass sampled (Table 4; Fig. 4). This indicates that the dissolved $\mathrm{EC}_{\mathrm{A}}$ reflected the population as a whole, as would be predicted if D-ATP was produced by excretion/exudation by growing and non-growing cells or by indiscrimin-
Fig. 3. Uptake rates for D-ATP versus depth for stations located in the RACER study area. All data are from the Jan 1987 cruise

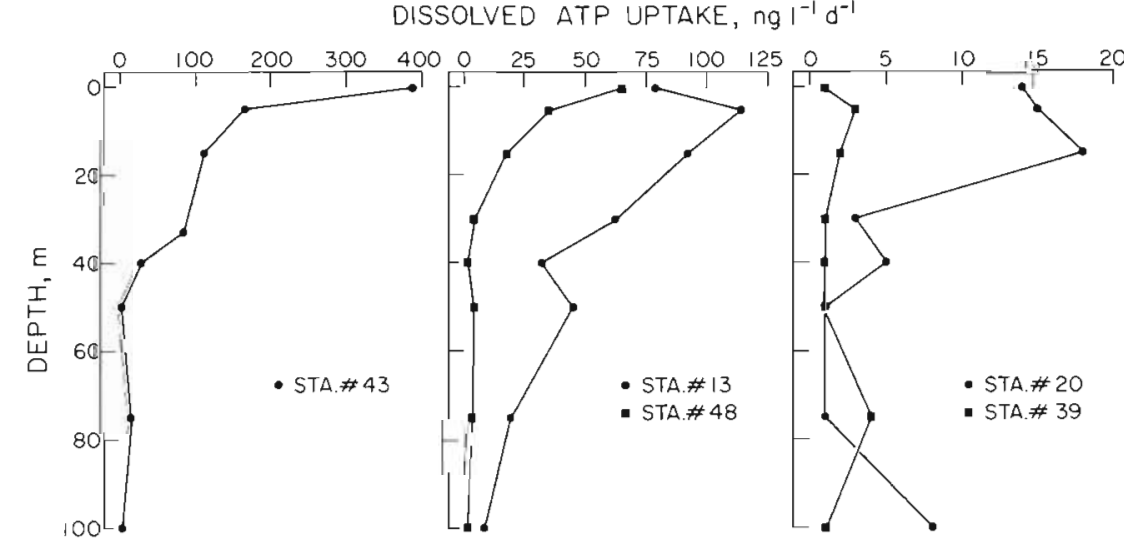


Table 4. Dissolved and total particulate adenylate energy charge ratios for water samples collected at 5 stations in the RACER study area from December 1986 to March 1987. All data are mean values ( \pm 1 standard deviation) estimated for the upper $50 \mathrm{~m}$ of the water column

\begin{tabular}{|c|c|c|c|c|}
\hline Station & Date & Dissolved $\mathrm{EC}_{\lambda}$ & Particulate $\mathrm{EC}_{A}$ & $D-E C_{A} / P-E C_{A}$ \\
\hline 13 & $\begin{array}{l}\text { Dec } 1986 \\
\text { Jan } 1987 \\
\text { Feb } 1987\end{array}$ & $\begin{array}{l}0.64( \pm 0.07) \\
0.57( \pm 0.10) \\
0.35( \pm 0.35)\end{array}$ & $\begin{array}{l}0.63( \pm 0.11) \\
0.66( \pm 0.09) \\
0.74( \pm 0.06)\end{array}$ & $\begin{array}{l}1.02 \\
0.89 \\
0.47\end{array}$ \\
\hline 20 & $\begin{array}{l}\text { Jan } 1987 \\
\text { Feb } 1987 \\
\text { Mar } 1987\end{array}$ & $\begin{array}{l}0.60( \pm 0.16) \\
0.42( \pm 0.15) \\
0.46( \pm 0.23)\end{array}$ & $\begin{array}{l}0.64( \pm 0.08) \\
0.59( \pm 0.06) \\
0.59( \pm 0.10)\end{array}$ & $\begin{array}{l}0.94 \\
0.71 \\
0.78\end{array}$ \\
\hline 39 & $\begin{array}{l}\text { Dec } 1986 \\
\text { Jan } 1987 \\
\text { Feb } 1987\end{array}$ & $\begin{array}{l}0.59( \pm 0.11) \\
0.39( \pm 0.05) \\
0.25( \pm 0.25)\end{array}$ & $\begin{array}{l}0.58( \pm 0.05) \\
0.67( \pm 0.03) \\
0.44( \pm 0.09)\end{array}$ & $\begin{array}{l}1.01 \\
0.58 \\
0.57\end{array}$ \\
\hline 43 & $\begin{array}{l}\text { Dec } 1986 \\
\text { Jan } 1987 \\
\text { Feb } 1987 \\
\text { Mar } 1987\end{array}$ & $\begin{array}{l}0.71( \pm 0.03) \\
0.51( \pm 0.02) \\
0.44( \pm 0.02) \\
0.49( \pm 0.20)\end{array}$ & $\begin{array}{l}0.65( \pm 0.03) \\
0.60( \pm 0.13) \\
0.71( \pm 0.06) \\
0.58( \pm 0.09)\end{array}$ & $\begin{array}{l}1.09 \\
0.85 \\
0.62 \\
0.84\end{array}$ \\
\hline 48 & $\begin{array}{l}\text { Dec } 1986 \\
\text { Jan } 1987 \\
\text { Feb } 1987\end{array}$ & $\begin{array}{l}0.67( \pm 0.04) \\
0.63( \pm 0.24) \\
0.56( \pm 0.09)\end{array}$ & $\begin{array}{l}0.68( \pm 0.06) \\
0.70( \pm 0.24) \\
0.70( \pm 0.05)\end{array}$ & $\begin{array}{l}0.98 \\
0.90 \\
0.80\end{array}$ \\
\hline
\end{tabular}

ant heterotrophic grazing activity. If the dissolved adenine nucleotides were derived from only the dying segment of the population, the dissolved $E C_{A}$ would be lower than the particulate $\mathrm{EC}_{\mathrm{A}}$ because only the subpopulation of stressed or moribund cells with low intracellular $\mathrm{EC}_{\mathrm{A}}$ would then contribute to the extracellular nucleotide pools. As phytoplankton cells account for $\geq 75 \%$ of the total microbial biomass in the early portion of the bloom (Holm-Hansen et al. 1987, Karl et al. unpubl.), they would appear to be a likely source of D-ATP. Later in the season, however, the particulate and dissolved $\mathrm{EC}_{\mathrm{A}}$ began to diverge (Table 4 ; Fig. 4). By the February and March cruises the dissolved and particulate $\mathrm{EC}_{\mathrm{A}}$ ratios were substantially different and D-ATP concentrations had subsided to barely detectable levels. While these results may be due to differential turnover rates of the individual dissolved adenine nucleotide compounds or differential rates of chemical hydrolysis, a more likely explanation would seem to be the result of the greater contribution of dissolved nucleotides from dead or dying cells (with low ECA $\mathrm{C}_{\mathrm{A}}$ ) during the post-bloom period. Temporal biomass changes observed in the RACER study area are consistent with this conclusion.

The peak accumulation of D-ATP occurred at 2 stations (nearshore Stn 43 and frontal zone Stn 13) in January. This accumulation could, in theory, be the result of either a decrease in D-ATP uptake rates or an increase in D-ATP production rates, or both. D-ATP turnover rates measured in January were on the order of days, not as rapid as reported from eutrophic British Columbia water (Azam \& Hodson 1977), but similar in magnitude to values measured in the western sector of McMurdo Sound (Holm-Hansen et al. 1977. Hodson et al. 1981a) and in the Gulf Stream frontal zone (Hodson et al. 1981b).

Grazing activity is a possible source of D-ATP that was not directly evaluated in the RACER program. However, an indirect assessment is possible by using 2 complementary RACER data sets. The first is the enumeration of heterotrophic microflagellate $(\leq 220$ $\mu \mathrm{m})$ populations by direct microscopy (G. Taylor \& D. Bird unpubl.). Microflagellate biomass ranged from $<200 \mu \mathrm{g} \mathrm{C} \mathrm{m}{ }^{-2}$ (integrated 0 to $100 \mathrm{~m}$ ) at Stn 20 to ca $900 \mu \mathrm{g} \mathrm{C} \mathrm{m}{ }^{-2}$ at Stn 43. If these potential micrograzers consumed their body weight per hour, and released all of the prey's ATP into the surrounding waters, this would account for less than $1 \%$ of the D-ATP flux measured at Stn 43 in January. Larger ciliated protozoans were more abundant than the heterotrophic mi-

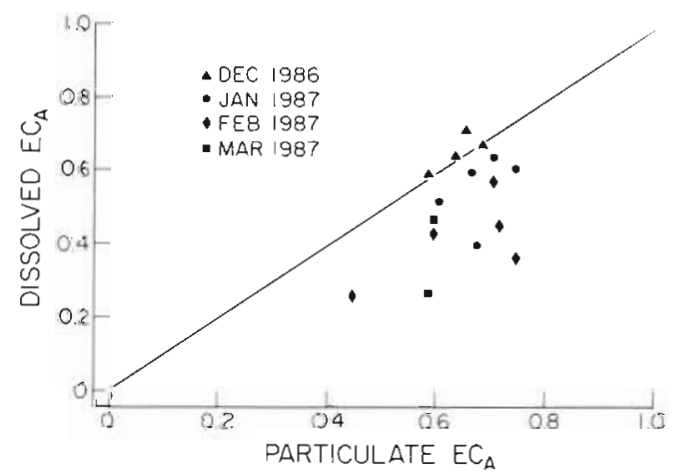

Fig. 4. Dissolved and particulate $\mathrm{EC}_{\mathrm{A}}$ ratios for samples measured during the RACER program. The values presented are the mean values estimated for the upper water column $(0$ to $50 \mathrm{~m}$ ) samples. The solid line is the 11 relation 
croflagellates during March (G. Taylor pers. comm.), but we have no data on their seasonal cycle or depthintegrated biomass distributions. Macrozooplankton grazing and release of ATP by 'sloppy feeding' (Lampert 1978) could also contribute to D-ATP flux. However, measurements of copepod (Calanus acutus) and larval krill (Euphausia superba) distributions and biomasses (M. E. Huntley pers. comm.) do not correspond with the spatial and temporal patterns that we observed for D-ATP concentrations. While the low concentrations and, presumably, low production rates of D-ATP in the late season may be maintained by microand macrozooplankton grazing activity, we believe that other processes (e.g. phytoplankton release of ATP and other adenine nucleotides) may represent more important mechanisms for the production of D-ATP in the RACER study area during and immediately following the spring bloom.

At present we can only speculate on the mechanism of ATP release from viable, metabolically active phytoplankton cells. One might argue, a priori, that growing cells should not leak, excrete or otherwise exchange their intracellular nucleotide pools (especially ATP) with the surrounding seawaters. This conclusion is based on the well-recognized importance of nucleotides for cellular energetics, macromolecular biosynthesis and metabolic regulation (Chapman et al. 1971, Karl 1980). Excretion of AMP by bacteria is a welldocumented phenomenon (Chapman et al. 1971, Leps \& Ensign 1979), especially as a mechanism for the regulation of intracellular $E_{C_{A}}$. Cyclic AMP release has also been documented for cultures of phytoplankton (Bressan et al. 1980, Francko \& Wetzel 1981a) and from aquatic macrophyte tissues (Francko \& Wetzel 1981b). However, excretion of ATP has not been previously documented. If we assume that the D-ATP uptake rates measured in our study are coupled to D-ATP production (as they must be over hour to day time scales), we can indirectly compare ATP production and release rates. Our largest ATP flux of $388 \mathrm{ng} \mathrm{l^{-1 }} \mathrm{d}^{-1}$ was measured for the surface waters at Stn 43. During this same period we observed a microbial biomass of $1400 \mathrm{ng} \mathrm{ATP} \mathrm{I}^{-1}$. If we conservatively assume that the microbial assemblage has a mean growth rate of 0.3 doublings $\mathrm{d}^{-1}$, and if we accept that the intracellular adenine nucleotide pool turns over 40 times per generation (Karl et al. 1987), then the P-ATP production rate

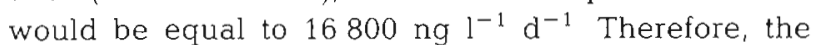
microbial assemblage present in the water column needs only to excrete ca 2 to $3 \%$ of their intracellular nucleotide pool in order to maintain the measured ATP flux at steady-state. These relatively low P-toD-ATP pool fluxes that might be required to support our field observations in the RACER study area are similar to the direct measurements of D-ATP and P-ATP pools in cultures of bacteria and algae (Berman et al. 1987). These calculations again support our conclusion that leakage of dissolved nucleotides (whether active or passive) from metabolically-active microorganisms may be an important mechanism for the formation of $D$ ATP in Antarctic coastal ecosystems.

In conclusion, we have measured spatial and temporal variations in the concentrations of $P$ - and D-ATP in a variety of coastal Antarctic environments. The field measurements were designed to evaluate the occurrence and production of D-ATP, with the goal of increasing our understanding of the transfer between particulate and dissolved organic pools in the ocean. Our results indicate a close correspondence between D-ATP and particulate biomass, and we conclude that phytoplankton release during active cell growth and metabolism is a major source of D-ATP during the spring bloom period in our study area. Micro- and macroheterotrophic grazing activities and release of DATP from dead or dying cells are probably important only during the later portion of the summer season.

Acknowledgements. We thank the officers and crew members of the MV 'Polar Duke and the RACER program scientists, especially G. Tien, M. Bailiff and G. Taylor, for their help in collecting and analyzing these samples during our 4 mo field study and G. Taylor, O. Holm-Hansen and 2 anonymous reviewers for constructive criticisms. This research was supported, in part, by a National Science Foundation grant DPP85-18748 awarded to D.M.K. Ms Lisa Wong cheerfully and flawlessly assisted in the preparation of the final manuscript. Contribution No. 216 of the Hawaii Institute of Geophysics.

\section{LITERATURE CITED}

Azam, F., Beers, J. R., Campbell, L., Carlucci, A. F., HolmHansen, O., Reid, F. M. H., Karl, D. M. (1979). Occurrence and metabolic activity of organisms under the Ross ice Shelf, Antarctica at station J9. Science 203: 451-453

Azam, F., Hodson, R. E. (1977). Dissolved ATP in the sea and its utilization by marine bacteria. Nature, Lond. 267 : 696-698

Azam, F., Holm-Hansen, O. (1973). Use of tritiated substrates in the study of heterotrophy in seawater. Mar. Biol. 23: 191-196

Bailiff, M. D., Jones, D., Nawrocki. M., Tilbrook, B., Haberstroh, P., Tien, G., Taylor, G. T., Karl, D. M. (1987). RACER: Bacterial abundance and thymidine incorporation in the Bransfield Strait, 1986-1987. Antarctic J. U.S. 22: $150-153$

Berman, T., Nawrocki, M., Taylor, G. T., Karl, D. M. (1987). Nutrient flux between bacteria, bacterivorous nanoplanktonic protists and algae. Mar. Microb. Food Webs 2: 69-82

Bressan, R. A., Handa, A. K., Cherniak, J., Filner, P. (1980). Synthesis and release of $\left[{ }^{32} \mathrm{P}\right]$-adenosine $3^{\prime}: 5^{\prime}$-cyclic monophosphate by Chlamydomonas reinhardtii. Phytochem. 19: 2089-2093

Chapman, A. G., Atkinson, D. E. (1977). Adenine nucleotide 
concentrations and turnover rates. Their correlation with biological activity in bacteria and yeast. Adv. microb. Physiol 15: 253-306

Chapman, A. G., Fall, L., Atkinson, D. E. (1971). Adenylate energy charge in Escherichia coli during growth and starvation. J. Bacteriol. 108: 1072-1086

Fellows, D. A., Karl, D. M., Knauer, G. A. (1981). Large particle fluxes and the vertical transport of living carbon in the upper $1500 \mathrm{~m}$ of the northeast Pacific Ocean. Deep Sea Res. 28: 921-936

Francko, D. A., Wetzel, R. G. (1981a). Dynamics of cellular and extracellular CAMP in Anabaena flos-aquae (Cyanophyta): intrinsic culture variability and correlation with metabolic variables. J. Phycol. 17: 129-134

Francko, D. A., Wetzel, R. G. (1981b). Synthesis and relase of cyclic adenosine $3^{\prime}: 5^{\prime}$-monophosphate by aquatic macrophytes. Physiol. Plant. 52: 33-36

Hodson, R. E., Azam, F., Carlucci, A. F., Fuhrman, J. A., Karl, D. M., Holm-Hansen, O. (1981a). Microbial uptake of dissolved organic matter in McMurdo Sound, Antarctica. Mar Biol. 61. 89-94

Hodson, R. E., Holm-Hansen, O., Azam, F. (1976). Improved methodology for ATP determination in marine environments. Mar Biol. 34: 143-149

Hodson, R. E., Maccubin, A. E., Pomeroy, L. R. (1981b). Dissolved adenosine triphosphate utilization by free-living and attached bacterioplankton. Mar. Biol. 64: 43-51

Holm-Hansen, O., Azam, F., Carlucci, A. F., Hodson,. R. E., Karl, D. M (1977). Microbial distribution and activity in and around McMurdo Sound. Antarctic J. U.S. 12: 29-32

Holm-Hansen, O., Letelier, R., Mitchell, B. G. (1987). RACER: temporal and spatial distribution of phytoplankton biomass and primary production. Antarctic J. U.S. 22: 142-145

Hulett, H. R. (1970). Non-enzymatic hydrolysis of adenosine phosphates. Nature, Lond. 225: 1248-1249

Huntley, M. E., Niiler, P., Holm-Hansen, O., Karl, D. M. (1987). Research on Antarctic Coastal Ecosystem Rates (RACER): an interdisciplinary field study. Antarctic J. U.S. 22: $135-137$

Iturriaga, R. (1981). Phytoplankton photoassimilated extracellular products: heterotrophic utilization in a marine environment. Kieler Meeresforsch. Sonderh. 5: 318-324

Jewson, D. H., Rippey, B. H., Gilmore, W. K. (1981). Loss rates from sedimentation, parasitism, and grazing during the growth, nutrient limitation, and dormancy of a diatom crop. Limnol. Oceanogr. 26: 1045-1056

Karl, D. M. (1980). Cellular nucleotide measurements and

This article was presented by Dr O. Holm-Hansen, La Jolla, California, USA applications in microbial ecology. Microbiol. Rev. 44 739-796

Karl, D. M., Holm-Hansen, O. (1978). Methodology and mea surement of adenylate energy charge ratios in environmental samples. Mat Biol. 48: 185-197

Karl, D. M., Jones, D. R., Novitsky, J. A., Winn, C. D., Bossard, P. (1987). Specific growth rates of natural microbial communities measured by adenine nucleotide pool turnover. J. Microbiol. Meth. 6: 221-235

Lampert, W (1978). Release of dissolved organic carbon by grazing zooplankton. Limnol. Oceanogr. 23: 831-834

Lancelot, C. (1979). Gross excretion rates of natural marine phytoplankton and heterotrophic uptake of excreted products in the Southern North Sea, as determined by shortterm kinetics. Mar. Ecol. Prog. Ser 1: 179-186

Larsson, U., Hagström, ̊. (1979). Phytoplankton exudate release as an energy source for the growth of pelagic bacteria. Mar. Biol. 52: 199-206

Laws, E. A., Archie, J. W (1981). Appropriate use of regression analysis in marine biology. Mar. Biol. 65: 13-16

Leps, W T.. Ensign. J. C. (1979). Adenylate nucleotide levels and energy charge in Arthrobacter crystallopoietes during growth and starvation. Arch. Microbiol. 122: 69-76

Maki, J. S., Sierszen, M. E., Remsen, C. C. (1983). Measurements of dissolved adenosine triphosphate in Lake Michigan. Can. J. Fish Aquat. Sci. 40: 542-547

McGrath, S. M., Sullivan, C. W. (1981). Community metabolism of adenylates by microheterotrophs from the Los Angeles Harbor and Southern California coastal waters. Mar Biol, 62: 217-226

Riemann, B. (1979). The occurrence and ecological importance of dissolved ATP in fresh water. Freshwater Biol. 9: $481-490$

Tien, T., Jones, D., Bailiff, M. D., Nawrocki, M., Tilbrook, B. Haberstroh, P., Taylor, G. T., Karl, D. M. (1987). RACER: spatial and temporal variations in microbial biomass Antarctic J. U.S. 22: 148-149

Wiebe, W. J., Smith, D. F. (1977). ${ }^{14} \mathrm{C}$-labeling of compounds excreted by phyoplankton for employment as a realistic tracer in secondary productivity measurements. Microbial Ecol. 4: 1-8

Williams, P. M., Druffel, E. R. M. (1987). Radiocarbon in dissolved organic matter in the central North Pacific Ocean. Nature, Lond. 330: 246-248

Wolter, K. (1982). Bacterial incorporation of organic substances released by natural phytoplankton populations. Mar Ecol. Prog. Ser. 7: 287-295

Manuscript first received: March 3, 1989

Revised version accepted: June 16, 1989 